\begin{tabular}{|l|c|c|c|c|c|}
\hline J. Tek. Ling & Vol.11 & No.1 & Hal. 79 - 85 & Jakarta, Januari 2010 & ISSN 1441-318X \\
\hline
\end{tabular}

\title{
KUALITAS PRODUK KOMPOS DAN KARAKTERISTIK PROSES PENGOMPOSAN SAMPAH KOTA TANPA PEMILAHAN AWAL
}

\author{
Firman L. Sahwan \\ Peneliti di Pusat Teknologi Lingkungan \\ Badan Pengkajian dan Penerapan Teknologi
}

\begin{abstract}
Early sorting process in composting municipal solid waste is labour intensive, so that the production cost is high. This research is carried out to know how the quality of the compost product and the characteristic of composting process if the early sorting is not done. The research result shows that without early sorting composting process has been done well, similar or not different significantly to the process with early sorting and has good quality. The positive result of this research is to increase the efficiency of the worker or reduce the production cost of manufacturing compost, because the process in making heap can increase from $1 \mathrm{~m}^{3}$ / person / day to $3 \mathrm{~m}^{3}$ / person / day.
\end{abstract}

Key Words: Compost, composing,municipal solid waste, sorting

\section{PENDAHULUAN}

\subsection{Latar Belakang}

Secara sederhana pengertian pengomposan adalah proses penguraian materi organik yang kompleks secara biologis oleh konsorsium mikroorganisme dengan menghasilkan materi organik yang sederhana dan relatif stabil menyerupai humus dalam kondisi yang terkendali ${ }^{1-6)}$ . Teknologi pengomposan sudah begitu berkembang, mulai dari sistem terbuka hingga sistem tertutup dengan menggunakan injeksi udara. Reaktor yang digunakan untuk proses pengomposan juga beragam, seperti reaktor menara tegak, reaktor horizontal, dan lain-lain, namun prinsip-prinsip dasarnya adalah sama. Hasil kajian BPPT terhadap teknologi pengomposan yang paling tepat untuk Indonesia berdasarkan kondisi iklim, ekonomi dan sosial budaya, adalah sistem terbuka (open window) atau modifikasinya $5,6)$.
Parameter yang mempengaruhi proses pembuatan kompos adalah $\mathrm{C} / \mathrm{N}$ ratio, kadar air, konstrasi oksigen, suhu, $\mathrm{pH}$, dan lain-lain dari bahan baku yang akan dijadikan kompos. Perbandingan antara Karbon dan Nitrogen (C/N ratio ideal adalah antara 20 sampai 40 banding 1 atau 30 banding 1 yang merupakan ratio terbaik. Sampah kota memiliki C/N ratio 30 sampai 40 banding 1 , sehingga cukup optimal untuk mendukung proses pembuatan pengkomposan dapat berjalan baik.

Pengomposan pada dasarnya merupakan proses penguraian materi organik sehingga sampah yang berpotensi untuk dijadikan kompos hanya bahan organiknya saja. Umumnya komposisi bahan organik sampah kota berkisar $60-80 \%$, sehingga memberikan peluang yang besar untuk bisa memanfaatkan sampah kota 
menjadi kompos. Dengan mengacu bahwa kadar air optimal suatu bahan agar proses pengomposan berjalan dengan baik berkisar antara $50-60 \%$, maka . sampah kota yang memiliki kadar air 40-60 \% akan menunjang berjalannya proses pengomposan.

Proses pengomposan merupakan proses aerob, oleh karena itu diperlukan paling sedikit $50 \%$ konsentrasi oksigen di udara dapat mencapai seluruh bagian bahan organik yang dikomposkan. Untuk memperoleh aerasi yang baik, maka ukuran dari bahan baku sebaiknya 2,5-7,5 $\mathrm{Cm}$. Sampah kota umumnya sudah memiliki ukuran tersebut, sedangkan untuk sampah kota yang memiliki ukuran terlalu besar, misalnya ranting pohon, kayu, daun yang lebar dan lain-lain, perlu dilakukan pemotongan atau pencacahan terlebih dahulu.

Berdasarkan uraian tersebut di atas dapat dikatakan bahwa sampah kota memiliki sifat dan karakteristik yang cukup baik atau cukup optimal untuk dijadikan sebagai bahan baku produksi kompos. Dari berbagai proyek percontohan, atau kegiatan produksi kompos yang sudah berjalan, terlihat bahwa proses pembuatan kompos dari sampah kota dapat berjalan dengan baik, dan telah menghasilkan kompos dengan kualitas yang baik pula.

Di Indonesia, potensi utama sampah kota terdapat pada jumlah sampahnya sendiri, jumlah yang sangat melimpah karena produksinya sebesar 2,9 liter per orang per hari. Apabila penduduk Indonesia diasumsikan berjumlah 200 juta jiwa maka akan terdapat sekitar $580.000 \mathrm{~m}^{3}$ atau 116.000 ton sampah per hari, merupakan suatu jumlah yang tidak sedikit. Namun demikian dalam pemanfaatannya sebagai kompos, terdapat beberapa kendala yang kurang menguntungkan. Salah satu permasalahan tersebut adalah belum adanya pemilahan sampah organik yang dapat dijadikan bahan pengomposan dari bahan anorganik di sumber sampahnya. Untuk itu dalam proses pembuatan kompos dari sampah kota tersebut harus dilakukan pemilahan bahan-bahan tersebut terlebih dahulu yang. Permasalahan yang muncul dalam proses pemilahan sampah kota sebagai bahan kompos adalah diperlukan tenaga kerja yang sangat banyak.. Secara rata-rata untuk 1 orang tenaga kerja selama 1 hari hanya bisa memilah $1 \mathrm{~m}^{3}$ sampah ${ }^{7)}$.

Permasalahan pemilahan sampah tersebut diatas melatar belakangi penelitian ini, yaitu tentang pengomposan yang dilakukan tanpa proses pemilahan bahan organik dan bahan anorganik terlebih dahulu. Didalam proses penelitian ini, kegiatan pemilahan tetap dilakukan tetapi hanya mengambil bahan bahan yang dianggap berbahaya (yaitu B3) bagi proses pengomposan serta membuka atau mengeluarkan bahan-bahan yang di bungkus kantong plastik. Sedangkan bahan anorganik seperti plastik yang sangat banyak dan terikut dalam proses pengomposan di asumsikan tidak mempengaruhi proses pengomposan sehingga tidak menurunkan kualitas kompos yang di hasilkan. Melalui penelitian ini diharapkan proses pemilihan awal dapat dilakukan secara jauh lebih cepat.

\subsection{Tujuan Penelitian}

Tujuan dari penelitan ini adalah untuk mengetahui kualitas produk kompos dan karakteristik suatu proses pengomposan, dengan bahan baku sampah kota tanpa melalui pemilahan awal terhadap campuran bahan organik dan anorganiknya terlebih dahulu.

\section{METODOLOGI}

\subsection{Tempat dan Waktu Penelitian}

Penelitian dilakukan di Tempat Pengolahan Sampah Terpadu (TPST) Rawasari, yang berlokasi di Jalan Rawasari Timur Dalam RT 11/RW 02, Kelurahan Cempaka Putih Timur, Kecamatan Cempaka Putih, Jakarta Pusat. Pengelolaan TPST Rawasari di laksanakan secara bersama antara Pusat Teknologi Lingkungan BPPT dan Dinas Kebersihan DKI Jakarta. Di dalam kompleks TPST Rawasari terdapat beberapa 
fasilitas pengelolaan sampah yaitu bangunan pengomposan sampah organik, bangunan dan mesin dan ulang sampah anorganik, TPS Indoor (Tempat Penampungan Sampah Sementara) dan incinerator kecil. Waktu penelitian dilaksanakan mulai tanggal 14 Agustus - 30 September 2008.

\subsection{Proses Pembuatan Kompos}

Proses pengomposan yang dilakukan dalam penelitian ini menggunakan sistem open window. Sampah yang berasal dari komplek pemukiman dibawa dengan gerobak sampah ke TPST Rawasari, setelah sampah diturunkan dari gerobak, sampah yang terbungkus plastik di keluarkan dan selanjutnya bahan berbahaya dan beracun (B3) yang ada dipisahkan. Setelah itu sampah dibuat tumpukan dengan ukuran panjang $6 \mathrm{~m}$, lebar $2,5 \mathrm{~m}$ dan tinggi $1,5 \mathrm{~m}$. Proses pembalikan (pengadukan) tumpukan dilakukan setiap minggu sekali. Penyiraman diberikan apabila tumpukan dianggap kering dan perlu disiram. Lama proses pembuatan kompos 7 minggu.

\subsection{Paramater Pengamatan}

Parameter yang diamati antara lain suhu harian dari tumpukan sampah yang dikomposkan, suhu udara harian, volume sampah setiap minggu sekali serta warna dan bau dari kompos pada akhir penelitian. Selain parameter tersebut juga dilakukan analisis terhadap sampel kompos hasil penelitian di Laboratorium Departemen IImu Tanah dan Sumberdaya Lahan IPB. Parameter yang dianalisa adalah Kadar air (KA), C/N ratio, $\mathrm{N}, \mathrm{P}, \mathrm{K}, \mathrm{Ca}, \mathrm{Mg}, \mathrm{pH}$, kadar garam dan logam berat lengkap.

\section{HASIL DAN PEMBAHASAN}

\subsection{Dinamika Temperatur Selama Proses Pengomposan}

Dinamika temperatur memainkan peranan yang paling penting dalam proses pengomposan karena menggambarkan indikator dari dinamika aktivitas mikrobiologi dalam proses pengomposan. Oleh karena itu profil perubahan temperatur menggambarkan pula karakteristik proses pengomposan yang sedang berjalan, bahkan menjadi parameter kunci kematangan, karena kompos dikatakan matang apabila temperatur kompos tidak lebih dari $20^{\circ} \mathrm{C}$ di atas temperature udara ${ }^{7)}$. Dinamika temperatur selama proses pengkomposan disajikan dalam Gambar 1.

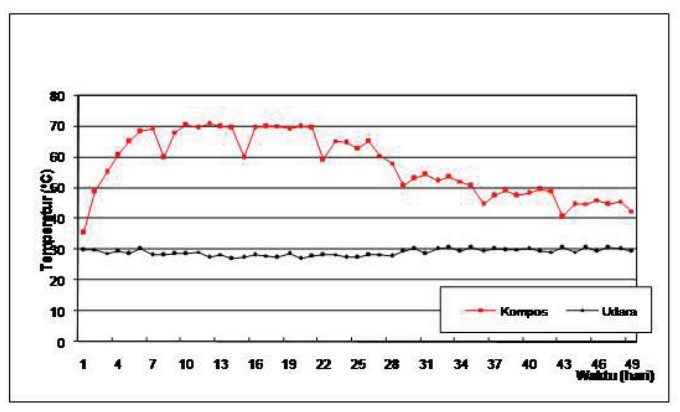

Gambar 1. Temperatur Udara dan Temperatur Tumpukan Sampah Kota yang Dikomposkan

Berdasarkan data pada Gambar 1 , terlihat dinamika temperatur yang menggambarkan proses pengomposan berlangsung baik seperti umumnya proses pengomposan secara aerobik berlangsung. Pada minggu ke 1 terlihat kenaikan temperatur yang sangat cepat yaitu 35,6 ${ }^{\circ} \mathrm{C}$ pada hari ke 1 menjadi $48,8^{\circ} \mathrm{C}$ pada hari ke $2,58,3^{\circ} \mathrm{C}$ pada hari ke 3 dan mendekati $70^{\circ} \mathrm{C}$ pada hari ke 7 (akhir minggu 1). Hal tersebut menggambarkan bahwa kondisikondisi optimal yang diperlukan dalam proses pengomposan seperti $\mathrm{C} / \mathrm{N}$ ratio, aerasi, kadar air dapat dipenuhi dalam penelitian ini sehingga aktivitas mikroba dapat berlangsung dengan baik, yang berarti pula proses pengomposan juga berlangsung dengan baik.

Meningkatnya temperatur dihasilkan dari metabolisme mikroba (hasil respirasi) dan terinsulasi oleh material yang dikomposkan. Mikroba tidak benar-benar efisien dalam mengkonversikan dan menggunakan energi 
kimia di dalam substrat. Energi yang tidak terpakai,dilepaskan dalam bentuk panas, semakin meningkat aktifitas mikroba, semakin tinggi panas yang dihasilkan.

Temperatur tertinggi yakni sekitar $70^{\circ} \mathrm{C}$ terjadi pada minggu ke 2 dan minggu ke 3 . Suhu yang tinggi ini menggambarkan aktivitas mikroba yang tinggi dalam menguraikan materi organik, dan juga berdampak positif dalam membunuh bakteri-bakteri patogen dan bibit gulma. Mulai minggu ke 4, terlihat indikasi temperatur yang mulai menurun,walaupun pada minggu ke 4 tersebut masih cukup tinggi $\left(60^{\circ} \mathrm{C}-65^{\circ} \mathrm{C}\right)$. Menurunnya temperatur mengindikasikan adanya penurunan aktivitas mikroba, sebagai akibat semakin sedikit materi organik yang harus diuraikan (dihancurkan) oleh mikroba. Kalau dikaitkan dengan temperatur udara yang antara $27,1^{\circ} \mathrm{C}-$ $30,8^{\circ} \mathrm{C}$, maka pada minggu ke 6 sudah terlihat adanya indikasi kematangan kompos karena temperatur kompos sudah berada dibawah $49,6^{\circ} \mathrm{C}$. Kematangan kompos tersebut semakin diperkuat karena pada minggu ke 7 , temperatur kompos semakin turun lagi, yaitu di bawah $46,2^{\circ} \mathrm{C}$. Kompos dikatakan matang, kalau temperatur kompos berada dibawah temperatur udara ditambah $20^{\circ} \mathrm{C}$ ).

\subsection{Reduksi Volume Selama Proses Pengkomposan}

Proses penguraian materi organik oleh mikroba telah mengakibatkan terjadinya reduksi volume karena sebagian besar dari unsur karbon pada materi organik diubah menjadi $\mathrm{CO}_{2}$. Proses penurunan volume disebabkan juga oleh proses pembalikan dan penguraian material limbah organik sehingga menyebabkan ukuran partikel semakin kecil dan semakin padat. Untuk itu reduksi volume yang merupakan akibat proses biokimia dari mikrobiologi pengomposan dapat juga dipakai sebagai salah satu parameter menentukan kematangan suatu proses pengomposan. Kompos dikatakan matang apabila reduksi volumenya melampaui $60 \%{ }^{7}$. Data reduksi volume selama proses pengkomposan disajikan dalam Gambar 2.

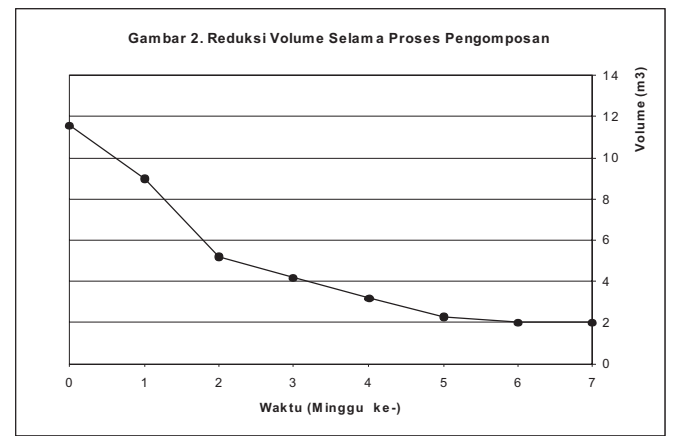

Gambar 2. Reduksi Volume Selama Proses Pengomposan

Berdasarkan data pada Gambar 2, terlihat bahwa dalam 2 minggu pertama terjadi reduksi volume yang tinggi (46\%) dan hal tersebut menggambarkan aktivitas mikroba yang sangat tinggi, sehingga dapat dikatakan bahwa proses pengomposannya berjalan normal dan biasa disebut sebagai pengomposan aktif. Angka reduksi volume sebesar tersebut, sama dengan angka-angka reduksi volume pengomposan sampah kota umumnya yaitu sebesar $50 \%$ pada 2 minggu pertama. Besarnya reduksi volume yang nyata, terlihat sampai akhir minggu ke 5 (besarnya reduksi volume sampai $80 \%$ ). Setelah itu, reduksi volume tidak lagi terlihat secara nyata. Keadaan tersebut menggambarkan bahwa aktivitas mikroba yang tinggi terjadi sampai akhir minggu ke 5 , atau ketersediaan makanan yang cukup bagi mikroba adalah sampai disaat tersebut. Waktu setelah akhir minggu ke 5 dapat dianggap sebagai proses stabilisasi atau tahap kematangan kompos. Kalau dihubungkan dengan parameter kematangan berdasarkan reduksi volume, juga sudah terpenuhi yaitu diatas $60 \%{ }^{7}$. Pada akhir minggu ke 6 atau ke 7 besarnya reduksi volume sebesar 82 $\%$, lebih tinggi dibandingkan dengan reduksi volume pengomposan sampah kota yang sebesar $70-75 \%$. Hal ini disebabkan karena pada setiap proses pembalikan, dilakukan pemilahan sampah plastik secara cepat, sehingga reduksi volume tak semata-mata karena proses biologis, tetapi juga karena pengurangan materi secara fisik. 


\subsection{Hasil Analisa Fisik dan Kimia Produk Kompos}

Untuk mengetahui kualitas fisik dan kimia produk kompos hasil penelitian, maka telah dilakukan analisa di Laboratorium Departemen IImu Tanah dan Sumberdaya Lahan, Fakultas Pertanian IPB. Hasil analisa disajikan di Tabel 1.

Berdasarkan data pada Tabel 1 , terlihat bahwa produk kompos hasil penelitian berkualitas baik karena memenuhi sebagian besar nilai ambang batas yang dipersyaratkan oleh SNI-Kompos dan tidak berbeda nyata dengan produk kompos TPST Rawasari yang diproduksi secara normal dengan melakukan pemilahan awal sebelum proses pengomposan berjalan. Nilai SNI-Kompos yang terlewati adalah logam berat $\mathrm{Fe}$, sehingga perlu pengkajian lebih lanjut apakah nilai tersebut memang tinggi atau ada kesalahan data. Tingginya nilai Fe tidak hanya pada produk kompos penelitian tetapi juga produk kompos yang di proses normal.

Tabel 1. Hasil Analisa Fisik dan Kimia Produk Kompos.

\begin{tabular}{|l|l|l|l|l|l|}
\hline \multirow{2}{*}{ No } & \multirow{2}{*}{ Parameter } & \multirow{2}{*}{ Satuan } & \multicolumn{2}{|c|}{ Nilai } & \multirow{2}{*}{ SNI-Kompos } \\
\cline { 4 - 6 } & & & Penelitian & Normal & \\
\hline 1 & Kadar Air & $\%$ & 13,06 & 19,20 & $<50 \%$ \\
\hline 2 & $\mathrm{pH}$ & - & 7,1 & 6,7 & $6,80-7,49$ \\
\hline 3 & $\mathrm{EC}$ & $\mu \mathrm{S} / \mathrm{cm}$ & 4800 & 5400 & - \\
\hline 4 & $\mathrm{C}$ & $\%$ & 17,76 & 14,92 & $9,80-32$ \\
\hline 5 & $\mathrm{~N}$ & $\%$ & 1,10 & 1,39 & $>0,40$ \\
\hline 6 & $\mathrm{P}$ & $\%$ & 0,31 & 0,37 & $>0,10$ \\
\hline 7 & $\mathrm{~K}$ & $\%$ & 0,78 & 0,69 & $>0,20$ \\
\hline 8 & $\mathrm{NH}$ & $\mathrm{ppm}$ & 116,1 & 96,75 & - \\
\hline 9 & $\mathrm{NO}$ & $\mathrm{ppm}$ & $5.398,65$ & $7.731,40$ & - \\
\hline 10 & $\mathrm{Ca}$ & $\%$ & 2,15 & 1,60 & $<25,50$ \\
\hline 11 & $\mathrm{Mg}$ & $\%$ & 0,24 & 0,26 & $<0,6$ \\
\hline & $\mathrm{Logam} \mathrm{Berat}$ & & & & \\
\hline 12 & $\mathrm{Fe}$ & $\mathrm{ppm}$ & 27.125 & 28.775 & $<20.000$ \\
\hline 13 & $\mathrm{Cu}$ & $\mathrm{ppm}$ & 82 & 565 & $<100.000$ \\
\hline 14 & $\mathrm{Zn}$ & $\mathrm{ppm}$ & 507,5 & 577,5 & $<500.000$ \\
\hline 15 & $\mathrm{Mn}$ & $\mathrm{ppm}$ & 532,5 & 595 & $<10.000$ \\
\hline 16 & $\mathrm{~Pb}$ & $\mathrm{ppm}$ & 1,37 & 0,92 & $<150.000$ \\
\hline 17 & $\mathrm{Cd}$ & $\mathrm{ppm}$ & 0,55 & 0,63 & $<3.000$ \\
\hline 18 & $\mathrm{Ni}$ & $\mathrm{ppm}$ & 0,82 & 0,54 & $<62.000$ \\
\hline 19 & $\mathrm{Cr}$ & $\mathrm{ppm}$ & 0,09 & 0,12 & $<210.000$ \\
\hline 20 & $\mathrm{Co}$ & $\mathrm{ppm}$ & 85 & 95 & $<34.000$ \\
\hline 21 & $\mathrm{Hg}$ & $\mathrm{ppm}$ & $\mathrm{tr}$ & $\mathrm{tr}$ & $<800$ \\
\hline
\end{tabular}

Catatan : Berdasarkan Uji Laboratorium IImu Tanah-IPB 
Nilai $\mathrm{C}$ total dan $\mathrm{N}$ total produk kompos menghasilkan $\mathrm{C} / \mathrm{N}$ ratio 16,15 untuk kompos penelitian dan $\mathrm{C} / \mathrm{N}$ ratio 10,74 untuk kompos normal. Kedua $\mathrm{C} / \mathrm{N}$ ratio yang dihasilkan menunjukkan bahwa kompos yang dihasilkan memenuhi tingkat kematangan karena $\mathrm{C} / \mathrm{N}$ ratio berada dibawah 201-4). Begitu juga nilai $\mathrm{N}-\mathrm{NH} 4$ menunjukkan nilai kematangan kompos karena berada dibawah $10 \%$ dari $\mathrm{N}$ total. Nilai kematangn tersebut juga didukung oleh sifat fisik dan produk kompos yaitu : strukturnya sudah halus, bebau seperti tanah dan warnanya coklat kehitaman.

\subsection{Efisiensi Tenaga Kerja}

Seperti telah diuraikan pada Bab Pendahuluan, secara umum sampah kota di Indonesia belum dilakukan pemilahan di sumber sampah. Kondisi demikian menyebabkan proses awal pembuatan kompos sampah kota harus dilakukan dari proses pemilahan untuk memisahkan sampah organic, dari sampah anorganiknya. yang dilanjutkan dengan pembuatan tumpukan sampah organik yang umumnya berukuran lebar 2,5 $\mathrm{m}$ dan tinggi 1,5 $\mathrm{m}$ dengan panjang sesuai dengan jumlah sampah yang akan dikomposkan. Dalam hal ini kemampuan rata-rata 1 orang tenaga kerja membuat tumpukan yang diawali dengan pemilahan adalah $1 \mathrm{~m}^{3}$ per hari ${ }^{7)}$.

Dengan pemilahan awal yang dilakukan secara cepat yaitu hanya mengambil bahanbahan yang dianggap berbahaya bagi proses pengomposan (B3) dan membuka atau mengeluarkan bahan-bahan yang dibungkus dengan kantong plastik besar, maka proses pembuatan tumpukannya mencapai $3 \mathrm{~m}^{3}$ per orang per hari. Hal tesebut menunjukkan bahwa dengan proses pemilahan cepat maka terjadi efisiensi tenaga kerja yaitu meningkatkan hasil pembuatan tumpukan sebesar tiga kali lipat.

Hasil kajian ini cukup menggembirakan karena bisa menurunkan biaya proses pembuatan kompos, dengan kualitas produk tetap baik dan proses pengomposan juga berjalan normal.

\section{KESIMPULAN DAN SARAN}

Berdasarkan hasil penelitian ini maka dapat disimpulkan sebagai berikut :

1. Karakteristik dari proses pengomposan tanpa pemilahan awal tetap berlangsung secara baik, dan normal seperti umumnya proses pengomposan sampah kota yang diawali dengan pemilahan awal.

2. Kualitas produk kompos penelitian juga baik dan tidak berbeda nyata dengan kualitas produk kompos dengan proses normal.

3. Proses pengomposan tanpa pemilahan awal telah meningkatkan efisiensi tenaga kerja, yaitu meningkatkan hasil pembuatan tumpukan dari $1 \mathrm{~m}^{3}$ menjadi $3 \mathrm{~m}^{3}$ per orang per hari

Sedangkan dari hasil penelitian dan kesimpulan tersebut dapat disarankan sebagai berikut :

1. Proses pengomposan tanpa pemilahan awal (pemilahan cepat) dapat diterapkan pada usahausaha pembuatan kompos yang menginginkan penurunan biaya produksi.

2. Untuk plant percontohan pembuatan kompos sampah kota yang berkaitan dengan penilaian kebersihan kota (Adipura) disarankan untuk tetap melakukan pemilahan awal. Hal ini disebabkan karena banyaknya sampah anorganik dalam proses pengomposan dianggap kurang baik sehinga dapat menurunkan penilaian kebersihan kota. 


\section{DAFTAR PUSTAKA}

1. Golueke, C.G., 1977, Biological Processing: Composting and Hydrolysis; In Handbook of Solid Waste Management, Van Nostrand Reinhold Company, New York.

2. Haug, R.T., 1980, Compost Engineering, Principles and Practice, An Arbor Science Publisher Inc., Michigan.

3. Tchobanoglous, G., H. Theisen and S. Vigil, 1993, Integrated Solid Waste Management, Engineering Principles and Management Issues, Mc GrawHill Inc, USA.
4. Epstein, E., 1997, The Science of Composting, Technomic Publishing Company Inc., USA

5. Wahyono, S., F.L. Sahwan dan F. Schuchardt, 2003, Pembuatan Kompos dari Limbah Rumah Potong Hewan, Pusat Pengkajian dan Penerapan Teknologi Lingkungan, BPPT, Jakarta.

6. Wahyono, S., F.L. Sahwan dan F. Suryanto, 2003, Menyulap Sampah Menjadi Kompos, Pusat Pengkajian dan Penerapan Teknologi Lingkungan, BPPT, Jakarta.

7. Anonim, 1996, Guidelines for Compost Quality, Canadian Quality, Canadian Council of Ministry of Enfiromental 